This item was submitted to Loughborough's Research Repository by the author.

Items in Figshare are protected by copyright, with all rights reserved, unless otherwise indicated.

\title{
Creditor protection and banking system development in India
}

PLEASE CITE THE PUBLISHED VERSION

PUBLISHER

(c) Loughborough University

VERSION

VoR (Version of Record)

LICENCE

CC BY-NC-ND 4.0

REPOSITORY RECORD

Deakin, Simon, Panicos Demetriades, and Gregory James. 2019. "Creditor Protection and Banking System Development in India”. figshare. https://hdl.handle.net/2134/5470. 
This item was submitted to Loughborough's Institutional Repository (https://dspace.lboro.ac.uk/) by the author and is made available under the following Creative Commons Licence conditions.

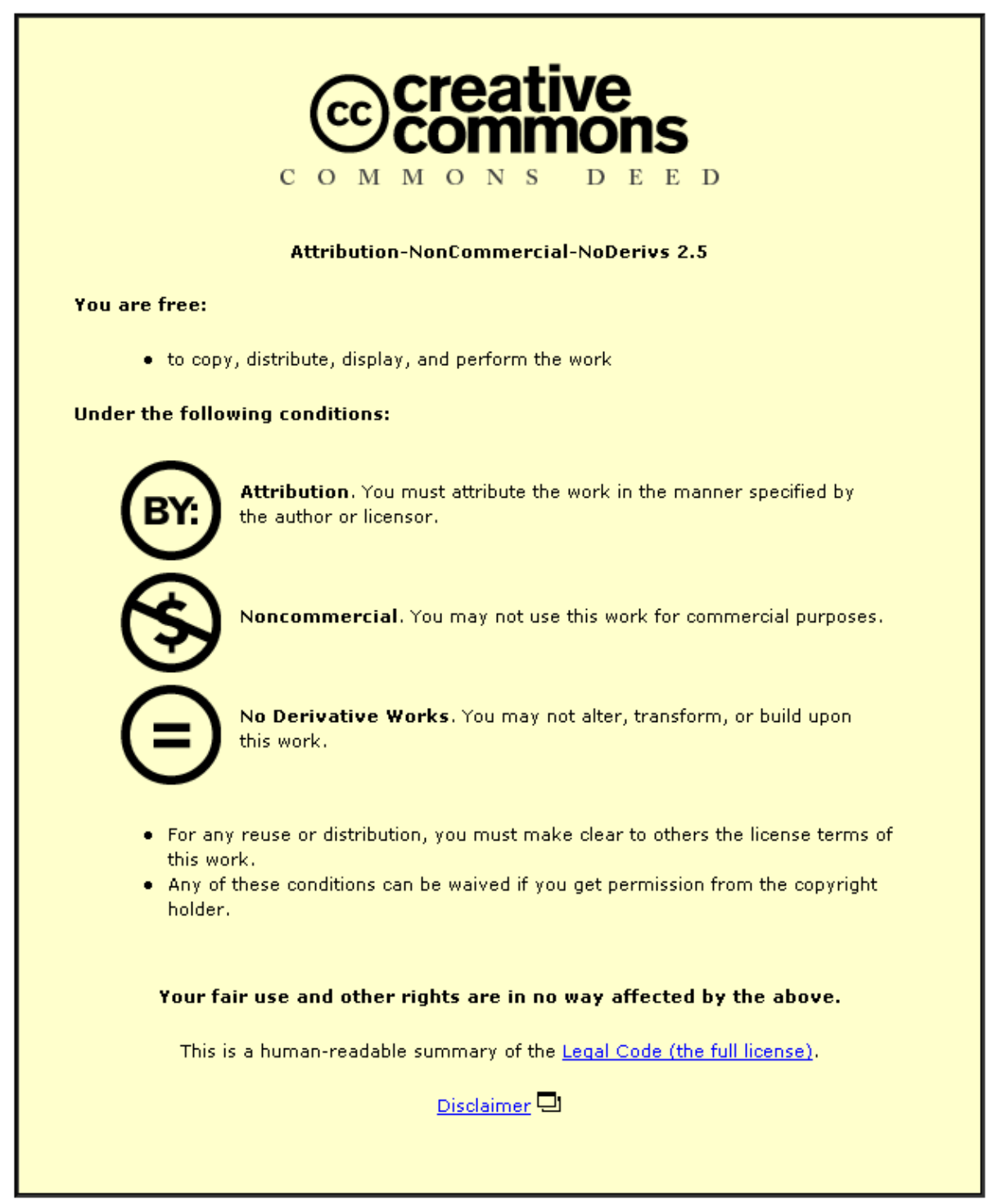

For the full text of this licence, please go to: http://creativecommons.org/licenses/by-nc-nd/2.5/ 
ISSN 1750-4171

\title{
DEPARTMENT OF ECONOMICS
}

\section{DISCUSSION PAPER SERIES}

\section{Creditor Protection and Banking System Development in India}

\author{
Simon Deakin \\ Panicos Demetriades \\ Gregory James
}

WP 2009 - 12 


\title{
Creditor Protection and Banking System Development in India $^{1}$
}

\author{
By \\ Simon Deakin ${ }^{2}$, Panicos Demetriades ${ }^{3}$ and Gregory James ${ }^{4}$
}

\section{Abstract}

We use a new legal dataset tracking changes in creditor protection law over several decades to study the impact of legal reforms on banking system development in India. Cointegration analysis is used to show that the strengthening of creditor rights in relation to the enforcement of security interests in the 1990s and 2000s led to an increase in bank credit. We show that the change in the law was not endogenous to trends in stock market development and GDP per capita, and that the direction of causation ran from legal reform to banking development, rather than the reverse.

Keywords: creditor rights, legal origin, banking development, India

JEL classification: G21, G38, K22, O16

\footnotetext{
${ }^{1}$ Simon Deakin and Panicos Demetriades acknowledge financial support from the ESRC's World Economy and Finance Research Programme (Award reference RES-156-25-0009 and RES-156-25-0037). Gregory James acknowledges financial support from the ESRC (Award reference PTA-026-27-1437).

${ }^{2}$ University of Cambridge

${ }^{3}$ University of Leicester

${ }^{4}$ Loughborough University
} 


\section{Introduction}

A substantial body of work has been devoted in recent years to the claim that legal systems shape financial outcomes. In particular, the content of laws protecting shareholder and creditor interests has been shown to be associated with cross-national variations in stock market development and private credit respectively (La Porta et al., 1998, Djankov et al., 2007). However, these findings largely rest on the analysis of crosssectional data. As such, they are subject to a number of limitations, in particular the possibility that changes to legal rules are endogenous to national contexts and macroeconomic trends (Rodrik, 2005).

One of the main obstacles to resolving the issue of endogeneity has, until recently, been the absence of reliable time series. This has now been addressed by the construction of longitudinal datasets which measure changes in the law over several decades (Lele and Siems, 2007; Deakin, Lele and Siems, 2007; Armour et al., 2008a, $2008 \mathrm{~b})$. The number of observations in these datasets and the length of the time series involved make it possible to use econometric methods that tackle the problem of endogeneity. In this paper we introduce one of these new datasets, the Creditor Protection Index (CPI), and analyse it to study the effects of changes in creditor rights in India on banking development.

\section{The Creditor Protection Index}

The CPI is one of several datasets which have been recently developed to provide a quantitative indicator of legal change over time; others cover the fields of shareholder protection and labour regulation (Armour et al., 2008). They draw on a wider range of legal materials and use a more finely-grained approach to coding than earlier studies. For example, the creditor rights index developed originally by La Porta et al. (1998) and more recently updated by Djankov et al. (2004) consists of just four variables: 'restrictions for going into reorganisation', 'no automatic stay on secured assets', 'secured creditors first' and 'management does not stay'. These are each coded on a binary ( 0 or 1 ) basis and the scores are then aggregated to provide a single indicator ranging from 0 (poor protection) to 4 (strong protection). The CPI constructed by 
Armour et al. (2008b) consists of 20 variables, some of which are broken down into subvariables, to give a total of 72 indicators in all. The variables are grouped into three categories. The first category, 'debtor control', refers to laws which restrict the activities of firms while they are going concerns, with a view to safeguarding creditor interests. These include laws setting minimum capital requirements and preventing sales of assets at an undervalue. The second category, 'creditor contracts', is concerned with the powers granted by the law to creditors to take and enforce security over the firm's assets. The third group of indicators, 'insolvency law', refers, among other things, to the circumstances under which a firm can enter into bankruptcy, how far it can thereby be shielded from its creditors, the priority of creditors' interests in insolvency, and the issue of who has control of the firm while the insolvency continues. An algorithm sets out, for each variable, the basis for the coding process. The sources for the coding are the original statutes and decisions of the jurisdictions concerned, and each change recorded in the index can be precisely traced to a primary legal source of this kind (this has not been the case with most earlier indices).

The CPI covers the period from the mid-1970s to the present day for five countries: France, Germany, India, the UK, and the USA. The CPI for India can be used to pinpoint legal changes which have taken place in relation to creditor rights in this period. India, as a common law system, inherited from English law a broadly protective approach towards the interests of secured creditors; its score on the law relating to creditor contracts was comparable to those of the UK and USA for the period under review, and considerably higher than those for France and Germany (Armour et al., 2008b). Indian law was strengthened at two points (see Armour and Lele, 2008). The Recovery of Debts due to Banks and Financial Institutions Act 1993 set up new bodies, known as Debt Recovery Tribunals, to speed up the debt recovery process for both secured and unsecured loans through a summary procedure. Then in 2002 the Securitisation and Reconstruction of Financial Assets and Enforcement of Security Interest Act gave the banks powers to enforce security interests without the need for a court order. In the CPI these changes were coded by increasing the score on one particular sub-variable, measuring the enforcement of security without a court order, from 0 to 0.5 in 1993 and 
then from 0.5 to 1 in 2008. These were two of 27 changes to legal rules which are recorded in the CPI for India between 1970 and 2005.

\section{Econometric Issues, Model Specification and Data}

Our empirical investigation has two aims. The first is to examine the direct effect of creditor protection law on banking system development in India, conditioning on variables that previous literature has found to influence banking sector development, such as real income and stock market development. ${ }^{5}$ The second aim addresses the issue of causality between banking system development and creditor protection, which can shed light on the question whether legal reform leads or follows financial outcomes.

We address the first aim by examining the statistical significance of CPI in a cointegrating system for banking system development which allows for the possible endogeneity of the regressors. Besides allowing the $\mathrm{CPI}$ to be endogenous, this accommodates all types of causal patterns between finance and growth. ${ }^{6}$ The second aim is addressed by carrying out a weak exogeneity test of the CPI with respect to banking system development.

Our sample consists of 30 annual observations from 1976 to 2005. Formally we estimate the following linear system with four variables in semilogarithmic form (where $u_{t}$ is an error term), normalised for convenience on banking system development:

$$
L B Y_{\mathrm{t}}=\mathrm{a}_{\mathrm{o}}+\mathrm{a}_{1} L Y_{\mathrm{t}}+\mathrm{a}_{2} L S M C_{t}+\mathrm{a}_{3} C P I_{t}+u_{\mathrm{t}}
$$

where LBY is the logarithm of the ratio of private bank credit to nominal GDP, LY is the logarithm of real GDP per capita and LSMC is the logarithm of the ratio of stock market capitalisation to GDP. The data on real GDP, bank credit, and stock market capitalisation were extracted from the World Bank Financial Structure Data Set (October 17, 2007).

\footnotetext{
${ }^{5}$ See, for example, Arestis et al (2001).

${ }^{6}$ There is a considerable body of empirical literature starting from Demetriades and Hussein (1996) which suggests that the relationship between finance and growth may be bi-directional. This has been confirmed in the case of India by Demetriades and Luintel (1997).
} 


\section{Empirical Results}

Unit root tests reported in Table 1 below suggest that the logarithms of $L Y, L B Y$, $\angle S M C$, and $C P I$ are integrated of order 1 and that their first differences are stationary. Thus equation (1) has the interpretation of a cointegrating vector for $L B Y$, in which the regressors are all $/(1)$.

\section{TABLE 1: AUGMENTED DICKEY FULLER TESTS}

ADF Statistic

\begin{tabular}{lll}
\hline Variables & Constant & Constant and Trend \\
\hline LBY & 1.3501 & 3.4626 \\
LY & 2.8617 & 1.8049 \\
CPI & -1.4798 & -1.8961 \\
LSMC & -0.2381 & $-3.8042^{* *}$ \\
DLBY & $-3.3722^{* *}$ & $-3.2242^{* * *}$ \\
DLY & $-5.1740^{*}$ & $-6.7498^{*}$ \\
DCRI & $-5.7233^{*}$ & -5.6776 \\
DLSMC & $-5.8199^{*}$ & $-5.1164^{*}$ \\
\hline
\end{tabular}

Notes: $* * *$, and $* * *$ indicate rejection of the unit root null hypothesis at the $1 \%, 5 \%$ and $10 \%$ level respectively

Using Johansen's MLE procedure ${ }^{7}$, we find evidence of at most one cointegrating vector among the set of variables, using both maximum eigenvalue and trace test statistics (Table 2). The cointegrating vector, normalised on banking sector development, shows a positive relationship between banking system development and

\footnotetext{
${ }^{7}$ Estimations were carried out in PcGive. We also obtained similar results using Hendry's dynamic single equation cointegration estimator. We prefer to report the results using Johansen's procedure as it treats all regressors as potentially endogenous.
} 
creditor protection, as well as a positive output effect. Stock market development is negatively related to banking system development, suggesting a possible crowding out effect. The hypothesis of weak exogeneity cannot be rejected in the case of output and creditor protection. The same hypothesis is rejected in the case of private credit and stock market capitalisation. Hence, there appears to be bidirectional causality between banking system development and stock market development whereas creditor protection is weakly exogenous to the cointegrating vector. Thus, the effects of creditor protection can be interpreted in a causal sense. Given that the coefficient on $C P I$ is significant at the $1 \%$ level, these results suggest that enhancements in creditor protection law have had a positive long run impact on financial development. ${ }^{8}$

TABLE 2: JOHANSEN COINTEGRATION TEST WITH THE CREDITOR PROTECTION COMPOSITE INDEX

\begin{tabular}{|c|c|c|c|c|c|c|c|c|}
\hline \multirow{4}{*}{$\begin{array}{l}\text { 2.A: } \\
\text { Sample: 1976- } \\
2005\end{array}$} & \multicolumn{3}{|c|}{ Estimated Cointegrating Vector } & $(L A G=2)$ & & & & \\
\hline & \multicolumn{4}{|c|}{ Trace Statistic } & \multicolumn{3}{|c|}{$\begin{array}{l}\text { Maximum Eigenvalue } \\
\text { Statistic }\end{array}$} & \\
\hline & \multicolumn{3}{|c|}{ Ho:rank $=p$} & \multicolumn{5}{|c|}{ Ho:rank $=p$} \\
\hline & $p=0$ & $p \leq 1$ & $p \leq 2$ & $p \leq 3$ & $p=0$ & $p \leq 1$ & $p \leq 2$ & $p \leq 3$ \\
\hline & $62.58^{*}$ & 27.5 & 13.62 & 6.1 & $35.07^{*}$ & 13.88 & 7.52 & 6.1 \\
\hline Normalised on $L B Y$ & & $L Y$ & & $C R I$ & & LSMC & & \\
\hline Coefficient & & 1.8190 & & 0.4279 & & -0.2297 & & \\
\hline S.E. & & 0.4467 & & 0.1512 & & 0.1239 & & \\
\hline \multicolumn{9}{|l|}{ Note: } \\
\hline \multicolumn{9}{|c|}{$*$ denotes rejection of the hypothesis at the $5 \%$ level. } \\
\hline \multirow[t]{2}{*}{ 2.B: } & \multicolumn{3}{|c|}{ Weak Exogeneity Tests } & & & & & \\
\hline & & $\angle B Y$ & & $L Y$ & & $C P I$ & & $\angle S M C$ \\
\hline LR test statistic & & 4.3045 & & 0.5738 & & 0.0004 & & 5.8047 \\
\hline$p$-value & & 0.038 & & 0.4487 & & 0.9839 & & 0.0159 \\
\hline
\end{tabular}

Note: $p$-values are that of the likelihood ratio tests under the null that the loading factor is zero.

\footnotetext{
${ }^{8}$ It is also worth noting that the qualitative nature of our main finding is robust to using alternative banking system development measures and adding variables such as the real interest rate - which was found to be insignificant - to the system.
} 
By construction, the creditor protection index is made of three sub-indices: debtor control, DEBT, creditor contracts, CREDIT, and insolvency, INSOLVENCY. Further estimations have shown that out of the three sub-indices, CREDIT is the sub-index which appears to be driving our results. The results using Johansen's MLE procedure and replacing the CPI with CREDIT are reported in Table 3. Both the maximum eigenvalue and trace test statistics provide evidence of at most one cointegrating vector among the new set of variables.

TABLE 3: JOHANSEN COINTEGRATION TEST WITH THE CREDITOR CONTRACTS SUB-INDEX

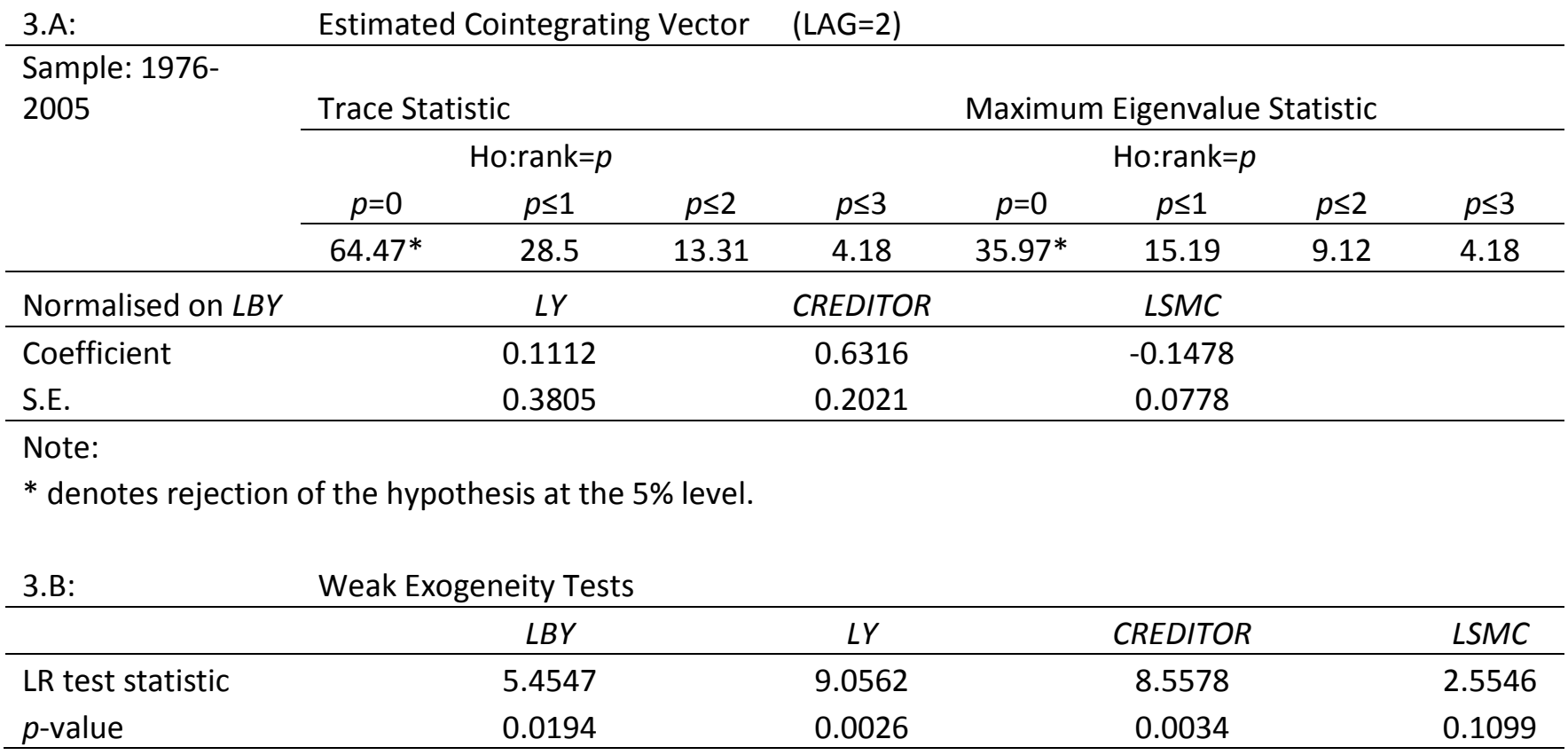

Note: $p$-values are that of the likelihood ratio tests under the null that the loading factor is zero.

Once again the cointegrating vector, normalised on banking sector development, exhibits a positive relationship between banking system development and creditor contracts, as well as a positive but this time insignificant output effect. Furthermore, stock market development continues to be negatively related to banking system development. The latter, however, is now found to be weakly exogenous to the banking system development vector. This suggests that stock market development has no longrun causal influence on banking system development but has an effect through the cointegrating parameter. The coefficient on $\angle S M C$ is significant at the $10 \%$ level. Finally, 
the weak exogeneity tests suggest a feedback relationship between banking system development, real GDP and creditor contracts since all three variables are now endogenous to the system.

\section{Concluding Comments}

Previous studies of the impact of legal change on financial markets, even when they used time-series data, were not able to overcome the problem that legal change may be endogenous to the economic cycle (Djankov et al., 2007: 323). In this paper we have shown how legal datasets covering a long time series can be combined with cointegration analysis to throw new light on this question. We saw, firstly, that legal reforms which strengthened creditor protection in India in the 1990s and 2000s were positively associated with banking development, measured by bank credit in relation to GDP per capita; secondly, that this association operated independently of trends in stock market development and GDP growth; and, thirdly, that the direction of causation ran from legal reforms to the growth of bank credit, rather than the reverse.

Although India is a common law system, we cannot conclude from our analysis that its legal origin was, as such, the driver of legal change. That would require a deeper analysis of relevant political and institutional forces (see Armour and Lele, 2008) and a comparison of India's experience with that of civil law systems (as in Armour et al., 2008a). We have, however, seen that legal change can be a significant factor, in its own right, in shaping financial outcomes; and, specifically, that changes to the law governing the enforcement of security interests may be an important means of encouraging bank lending in a developing country context.

\section{References}

Arestis, P., Demetriades, P.O., Luintel, K.B., 2001. Financial development and economic growth: the role of stock markets. Journal of Money, Credit and Banking 33: 16-41.

Armour, J., Deakin, S., Sarkar, P., Siems, M., Singh, A., 2008a. Shareholder protection and stock market development: an empirical test of the legal origins hypothesis. ECGI Law Working Paper No. 108/2008. 
Armour, J., Deakin, S., Lele, P., Siems, M., 2008b. How legal rules evolve: evidence from panel data. Paper presented to the Annual Conference of the Law and Society Association, Berlin, July 2007; forthcoming, CBR Working Paper series, September 2008 (http://www.cbr.cam.ac.uk).

Armour, J., Lele, P., 2008. Law, finance and politics: the case of India. ECGI Law Working Paper No. 107/2008.

Deakin, S., Lele, P., Siems, M., 2007. The evolution of labour law: calibrating and comparing regulatory regimes. International Labour Review 146, 133-162.

Demetriades, P.O., Hussein, K.A., 1996. Does financial development cause economic growth? Time-series evidence from 16 countries. Journal of Development Economics 51, 387-411.

Demetriades, P.O., Luintel, K.B., 1997. The direct costs of financial repression: evidence from India. Review of Economics and Statistics, 79: 311-320.

Djankov, S., Hart, O., McLeish, C., Shleifer, A., 2007. Private credit in 129 countries. Journal of Financial Economics 84, 299-329.

La Porta R., Lopez-de-Silanes F., Shleifer A., Vishny R., 1998. Law and finance. Journal of Political Economy 106, 1113-55.

Lele, P. and Siems, M., 2007. Shareholder protection: a leximetric approach. Journal of Corporate Law Studies 7, 17-50.

Rodrik, D., 2005. Why we learn nothing from regressing economic growth on policies. Working paper, Harvard University:

http://ksghome.harvard.edu/ drodrik/policy\%20regressions.pdf. 